\title{
The Effect of Leachate Waters on the Quality of Free Groundwater in Air Dingin Landfill, Padang City
}

\author{
*Takdir Alamsyah ${ }^{1}$, Eri Barlian ${ }^{2}$, and Nurhasan Syah $^{2}$ \\ ${ }^{1}$ Student of Environmental Sciences, Postgraduate of Universitas Negeri Padang, Indonesia \\ ${ }^{2}$ Lecturer of Environmental Sciences, Postgraduate of Universitas Negeri Padang, Indonesia \\ Email : takdiralamsyah32@gmail.com
}

*Corresponding Author, Received: Februari 10, 2019, Revised: April 10, 2019, Accepted: May 10, 2019

\begin{abstract}
The purpose of this study is 1) to know the condition of physical parameters, free groundwater chemistry; 2) to what extent of leachate water contamination of against free groundwater in the Air Dingin landfill, Padang City. The data analysis technique used in this study is based on Minister of Health Regulation Number 419/1990 concerning Water Quality Requirements and Supervision, and Government Regulation Number 82/2010 concerning Management of Water Quality and Water Pollution Control. The water quality physics test results show 1) smell and taste meet the quality standard requirements; 2) water temperature meets quality standard requirements; 3) water colour meets quality standard requirements; 4) Dissolved Solids (TDS) meet the quality standard requirements; and 5) Suspended Solids (TSS) meet the quality standard requirements, while the chemical quality of water shows 1) $\mathrm{pH}$ below the quality standard;2) Arsenic below the quality standard; 3) Cadmium is below the quality standard; 4) Chromium below the quality standard; 5) Iron below the quality standard; 6) Lead below the quality standard; 7) Manganese below the quality standard; 8) Free groundwater below the quality standard; and 9) COD below the quality standard.. Leachate water that comes out laterally from the garbage pile tends to flow following the contour of the land towards a lower direction.
\end{abstract}

Keywords: Leachate Water, Contamination, Water Quality, Landfill, Padang City

\section{Introduction}

Rapid growth and development of the population, especially in large cities, has resulted in increasingly widespread residential areas, this situation has led to an increase in the volume of waste produced both solid waste and liquid waste (Abdel-Shafy and Mansour, 2018). Soekmana (2010) suggests that waste management in urban environments and settlements and industries is a major problem in handling waste in Indonesian cities. Furthermore, it was stated that the type of waste increased along with technological progress and experienced rapid diversification.

The general characteristics of municipal waste vary greatly, this is due to the variety of existing community activities such as food scraps, wood, paper, organic substances, textiles, plastics, bones, glass, metal and soil and so on (Hermon, 2010; Suharno, 2012; Hermon, 2012; Tchounwou et al, 2012; Hermon, 2015; Hermon, 2016; Hermon, 2017). Waste landfill, besides having a very important function, can also have an impact on the decline in environmental quality. The decrease in environmental quality is caused by the piles of garbage that produce various wastes in the form of foul-smelling gas, liquid waste that pollutes ground water and river water, and as a place of life for disease factors. Leachate formed from the decomposition of waste, food scraps or plants mixed with rainwater is one of the environmental problems 
that are very closely related to cleanliness, health, beauty and comfort. The more population will result in the volume of waste produced will continue to increase as well. Munawar (2012); Townsend (2018) states that leachate which is at the surface of the ground can cause pollution in groundwater and surface water. This leachate will partially enter the soil through infiltration and some will flow on the surface of the ground looking for a lower place towards the river and eventually towards the ocean and some of it evaporates due to wind gusts and high temperatures. Putra (2012); Hermon et al., (2017) explains a waste landfill that is close to residential areas, is an area that is believed to be an expansion of residential areas or in watersheds, springs, ponds and other public facilities. So the management of waste landfill must receive special attention so that the place will not be polluted later. The purpose of this study is 1) to know the condition of physical parameters, free groundwater chemistry; 2) to what extent of leachate water contamination of against free groundwater in the Air Dingin landfill, Padang City.

\section{Method}

The data analysis technique used in this study is laboratory analysis, where we want to know the quality of free groundwater around the waste disposal site and analyzed descriptively based on the Minister of Health Regulation Number 419/1990 concerning Water Quality Requirements and Supervision and the Government Regulation Number 82/2010 concerning Management of Water Quality and Water Pollution Control. The physics and chemistry parameters are tested as Table 1.

Table 1. Clean Water Quality Standards

\begin{tabular}{clccc}
\hline No & \multicolumn{1}{c}{ Parameter } & Unit & Quality standards & Method Specifications \\
\hline physics & & & \\
\hline 1 & Smell & - & & \\
2 & Taste & - & Suhu udara $\pm 3^{\circ} \mathrm{C}$ & Termometer \\
3 & Temperature & ${ }^{\circ} \mathrm{C}$ & 50 & SNI :06-6989.3-2004 \\
4 & Colour & $\mathrm{Skl} \mathrm{TCU}$ & 1500 & TDS Meter \\
5 & TDS Dissolved Substances & $\mathrm{mg} / \mathrm{L}$ & $50 *$ & SNI:06-6989.3-2004 \\
6 & Suspended residue & $\mathrm{mg} / \mathrm{L}$ & & \\
\hline chemistry & - & $6,5-9.0$ & SNI:06-6989.11-2005 \\
\hline 1 & Degree of acidity of pH & $\mathrm{mg} / \mathrm{L}$ & 0,05 & Strip Test \\
2 & Arsenic (As) & $\mathrm{mg} / \mathrm{L}$ & 0,005 & SNI :06-2513-1991 \\
3 & Cadmium (Cd) & $\mathrm{mg} / \mathrm{L}$ & 0,5 & SNI :06-2513-1991 \\
4 & Chromium (Cr) & $\mathrm{mg} / \mathrm{L}$ & 1,0 & WI-M-K 1BLK-SB \\
5 & Iron (Fe) & $\mathrm{mg} / \mathrm{L}$ & 0,05 & SNI :06-6989.3-2004 \\
6 & Lead (Fb) & $\mathrm{mg} / \mathrm{L}$ & 0,5 & SNI :06-6989.5-2004 \\
7 & Manganese (Mg) & $\mathrm{mg} / \mathrm{L}$ & $2,0 *$ & SNI :06-2503-1991 \\
8 & BOD.5 & $\mathrm{mg} / \mathrm{L}$ & $10,0 *$ & SNI :06-6989.15-2004 \\
9 & COD &
\end{tabular}

\section{Result and Discussion}

In Air Dingin Landfill, waste management still uses an open damping system, where the garbage that comes from the truck is stacked at a location and then spread out and at the same time compacted by using Dozers and Exsavators to all specified locations. Every day the garbage that goes into the Landfill is around 370 to 400 tons, there is no separation of waste by type according to the type of landfill, but the efforts of waste collectors try to find the remaining waste that they can still use. The use of geotextile/geomembrane on the soil surface which will be piled up with garbage is intended to reduce the infiltration of leachate and at the same time facilitate control of leachate. Leachate water control is carried out by a manual system by making land channels/drainage around the landfill. This land channel is used to hold leachate out of the rubbish pile, especially in the rainy season, which will increase the production of leachate. Leachate collected in the channel has then flowed through PVC pipes into stabilization ponds located on the north side of the landfill.

The stabilization pond at the waste landfill serves to neutralize leachate from suspended material and other floating impurities that enter the pond simultaneously. The stabilization pool consists of several 
columns which will neutralize naturally leachate. In stabilization ponds, leachate is processed naturally to neutralize pollutants before leachate is disposed of into the river. This method is used in Air Dingin landfill because the area has tropical temperatures and is sufficient to receive sunlight at all times, processing leachate in this way does not require a large amount of money when compared with a mechanical leachate treatment system.

According to the Minister of Health Regulation Number 419/1990 concerning the quality requirements for clean water that water must not smell and taste. The results of the study of free groundwater around Air Dingin landfill $80 \%$ of the test samples meet the requirements for clean water quality. Water temperature according to the Minister of Health Regulation Number 419/1990 concerning the quality of clean water, where the water temperature is the same as the air temperature around the sampling point $\pm 3{ }^{\circ} \mathrm{C}$. From the temperature measurements carried out that all free groundwater temperatures meet the requirements and in accordance with Minister of Health Regulation.

To determine the colour of water in this study carried out in a visual way (Hermon, 2014; Oktorie, 2017; Hermon, 2019). From the results of observations on existing water samples that the free groundwater in the Air Dingin landfill area is colourless and fulfils the requirements as stated in Minister of Health Regulation Number 419/1990. According to the Minister of Health Regulation Number 419/1990 concerning the requirements for the quality of clean water that the dissolved solids content (TDS) in water should not exceed $1500 \mathrm{mg} / \mathrm{L}$. The results of the study of free groundwater around Air Dingin landfill 100\% of the test samples meet the requirements for Quality of clean water. According to the Minister of Health Regulation Number 419/1990 concerning the requirements for clean water quality that the TSS content in water should not exceed $50 \mathrm{mg} / \mathrm{L}$. The results of the study of free groundwater around Air Dingin landfill 100\% of the test samples meet the requirements for quality of clean water.

According to the the Minister of Health Regulation Number 416 of 1990 standard about the quality of clean water that the $\mathrm{pH}$ of normal groundwater ranges from 6.0 to 9.5 . The $\mathrm{pH}$ value obtained in this study shows that $100 \%$ of the samples tested do not meet the requirements as in the Indonesian Minister of Health Regulation. According to the the Minister of Health Regulation Number 416 of 1990 concerning the quality of clean water, the maximum chemical element of Arsenic contained in clean water is $1.5 \mathrm{mg} / \mathrm{L}$. The content of Arsenic chemical elements for all sample tests is below the quality standard determined by the Minister of Health Regulation.

According to the the Minister of Health Regulation Number 416 of 1990 concerning the quality of clean water, the chemical element of Cadmium in clean water is a maximum of $0.005 \mathrm{mg} / \mathrm{L}$. The laboratory test results for free groundwater around Air Dingin Landfill show that $100 \%$ of the Cadmium content tested from the sample is below the threshold determined by the Minister of Health Regulation. According to the the Minister of Health Regulation Number 416 of 1990 concerning the quality of clean water, the chemical element of Chromium in clean water is a maximum of $0.5 \mathrm{mg} / \mathrm{L}$. The laboratory test results of free groundwater around the Air Dingin landfill show that $100 \%$ of the samples tested for the content of Chromium tested from the sample are below the threshold determined by the Minister of Health Regulation.

According to the the Minister of Health Regulation Number 416 of 1990 concerning the quality of clean water, the chemical element of iron in clean water is a maximum of $1.0 \mathrm{mg} / \mathrm{L}$. The laboratory test results of free groundwater around the Air Dingin landfill show that $100 \%$ of the testing samples of iron chemical content are below the threshold determined by the Minister of Health Regulation. According to the the Minister of Health Regulation Number 416 of 1990 concerning the quality of clean water, the chemical element of Lead in clean water is a maximum of $0.05 \mathrm{mg} / \mathrm{L}$. The results of laboratory tests for free groundwater around Air Dingin Landfill show $100 \%$ of the test sample, the Lead content of the sample is below the threshold that has been determined by the Minister of Health Regulation.

According to the Minister of Health Regulation Number 416 of 1990 concerning the quality of clean water, the maximum chemical element of Manganese in clean water is $0.5 \mathrm{mg} / \mathrm{L}$. Laboratory test results of free groundwater around Air Dingin Landfill show 100\% of the number of test samples, the Manganese content is below the threshold determined by the Minister of Health Regulation. According to the Government Regulation Number 82/2010 regarding class 1/clean water quality, Biology Oxigen Demand in clean water is a maximum of $2 \mathrm{mg} / \mathrm{L}$. The laboratory test results of free groundwater around the Air Dingin landfill show that $80 \%$ of the content testing samples are below the threshold determined by the Government. 
According to the Government Regulation Number 82/2010 concerning class 1/clean water quality, Biology Oxigen Demand in clean water is a maximum of $10 \mathrm{mg} / \mathrm{L}$. The laboratory test results of free groundwater around the Air Dingin landfill show that $90 \%$ of the samples tested for COD content are below the threshold determined by the Government.

Leachate water that comes out laterally from the garbage pile tends to flow following the contour of the land towards a lower direction. In Air Dingin Landfill control of leachate is done by making a parid/perimeter channel around the location of the garbage accumulation, this perimeter channel serves to hold leachate out through the lateral direction and then channel it through PVC pipes to the processing pond. The existing channel is still a land channel so that the infiltration process of leachate into the ground is still running. Leachate water that enters into the vertical direction /infiltration soil will fill the empty soil deposits above the ground water level and cause free groundwater to be pushed and at the same time contaminated with leachate. Thus the process of pollution of free ground water by leachate water has begun, such conditions will last for a long time until the soil experiences a saturation limit. Geological conditions are called vulnerable if the bedrock of landfill is porous and or contains many cracks. This condition will facilitate the seepage of leachate, which will then reach the ground water level so that it mixes the surface ground water with leachate. Generally, the soil around Air Dingin Landfill is Clay or clay, where the clay has low porosity, this is because clay has fine and stiff grains when compared to sandy soils, such soil conditions greatly help block the infiltration of leachate into so that leachate water does not affect the condition of free groundwater.

\section{Conclusion}

Referring to the findings and results of the research that has been carried out, it can be concluded that the quality of free groundwater in the vicinity of Air Dingin Landfill generally meets the requirements in accordance with the Minister of Health Regulation Number 416 of 1990 and the Government Regulation Number 82/2010. Based on laboratory tests conducted on 10 research samples, it was shown that only in study sample No. 5 and research sample No. 8 the water was smelling and tasteless and for research sample No. 1 the value of BOD and COD was slightly above the required quality standard. The chemical elements of $\mathrm{pH}$ for all research samples show that the $\mathrm{pH}$ value is below the prescribed quality standard. In general, leachate water that comes out of the pile of garbage does not significantly affect the condition of free groundwater around the Air Dingin Landfill, this can be seen with no increase in the physical and chemical elements of free groundwater around the Air Dingin Landfill.

\section{References}

Abdel-Shafy, H. I and Mansour, M. S. 2018. Solid waste issue: Sources, composition, disposal, recycling, and valorization. Egyptian journal of petroleum.

Government Regulation Number 82/2010. 2010. Management of Water Quality and Water Pollution Control.

Hermon, D. 2010. Geografi Lingkungan: Perubahan Lingkungan Global. UNP Press.

Hermon, D. 2012. Mitigasi Bencana Hidrometeorlogi: Banjir, Longsor, Degradasi Lahan, Ekologi, Kekeringan, dan Puting Beliung. UNP Press. Padang.

Hermon, D. 2014. Impacts of Land Cover Change on Climate Trend in Padang Indonesia. Indonesian Journal of Geography. Volume 46. Issue 2. p: 138-142. Fakultas Geografi Universitas Gajah Mada.

Hermon, D. 2015. Geografi Bencana Alam. Jakarta: PT RajaGrafindo Persada.

Hermon, D. 2016. Mitigasi Perubahan Iklim. Rajawali Pers (Radjagrafindo).

Hermon, D. 2017. Climate Change Mitigation. Rajawali Pers (Radjagrafindo).

Hermon, D., P. Iskarni., O. Oktorie and R. Wilis. 2017. The Model of Land Cover Change into Settlement Area and Tin Mining and its Affecting Factors in Belitung Island, Indonesia. Journal of Environment and Earth Science. Volume 7 No. 6. p: 32-39. IISTE. 
Hermon, D. 2019. Evaluation of Physical Development of The Coastal Tourism Regions on Tsunami Potentially Zones in Pariaman City-Indonesia. International Journal of GEOMATE. Volume 17. Issue 59. p: 189-196. Geomate International Society.

Minister of Health Regulation Number 419/1990. 1990. Water Quality Requirements and Supervision.

Munawar. 2011. Rembesan Air Lindi (Lenchate) Surabaya, Penerbit. UPN Perss.

Oktorie, O. 2017. A Study of Landslide Areas Mitigation and Adaptation in Palupuah Subdistrict, Agam Regency, West Sumatra Province, Indonesia. Sumatra Journal of Disaster, Geography and Geography Education. Volume 1. Issue. 1. p: 43-49. Master Program of Geography Education.

Townsend, T. G. 2018. Landfill bioreactor design \& operation. Routledge.

Putra, A. 2012. Studi Erosi Lahan Pada DAS Air Dingin Bagian Hulu di Kota Padang. Skripsi, Universitas Negeri Padang.

Soekmana, S. 2010. Pengantar Imu Teknik Lingkungan.Bogor, Penerbit, IPB Pers.

Suharno, A. 2012. Dasar-dasar Teknologi Pengolahan Air Limbah,Yokyakarta, Penerbit, Gosyen Publishing.

Tchounwou, P. B., Yedjou, C. G., Patlolla, A. K., \& Sutton, D. J. 2012. Heavy Metal Toxicity and The Environment. In Molecular, Clinical and Environmental Toxicology (pp. 133-164). Springer, Basel. 